\title{
Introduction
}

\section{Queering Health and Biomedicine}

over ReCEnt DeCADEs, in the Nordic countries as elsewhere in the Global North, the status of the embodied self in the context of biomedicine and broader healthcare systems has become increasingly linked to ideas of autonomous choice and bodily independence. The call to self-sufficiency and personal responsibility has been central to the rise of neoliberalism, with its promotion of market-based health care systems and the aim of diminishing the expenditure of the state sector. The practical impossibility inherent in such idealized individualism has contributed to a growing awareness of how human beings are inextricably interwoven and interdependent with others - human and non-human; organic and inorganic - and that all life is reliant on these entanglements. This posthuman emphasis on our lived embodied realities and the fundamental inter-relatedness between humans and their "others" (Braidotti 2013) means that the foundational conceptual and material "object" of biomedicine and health care - the bounded, individualized biological-machine body - is problematized. The rhetoric of individualism at the heart of neoliberalism and the recognition of practical interdependency always sit uneasily together, but the conjunction is at its most troubling in biomedical interventions into the body. Cru- 
cially, many recent bioscientific technologies have exposed the limits of both human agency and the bounded body, while biological research has opened up a startling new understanding of the parameters of the human itself. As editors of this special issue of lambda nordica on Queering Health and Biomedicine, we have embraced that unease to explore how the paradigms not just of health but of embodiment require continual queering and renegotiation.

While the effects of neoliberalism on health and our interdependency with others have been explored by critical scholars from different backgrounds, this special issue focuses on a specific dimension of engaging with ongoing developments around health and bodies: queering biomedicine. The project of queering biomedicine seeks to include experiences, bodies and identities that do not fit neatly into a norm assumed to have universal reach, thereby expanding the object of biomedical research and practice to the specific experiences and bodies of queer people, along with others who do not fit into dominant normative frameworks. On a practical level, the importance of this aspect can hardly be exaggerated given the gaps in knowledge and understanding of queer health issues and the consequences of this for practices of care and for the health and well-being of queer people. At the same time, practices of inclusion are also often viewed with a fair amount of suspicion, and rightly so, as they risk upholding and further strengthening normalizing tendencies and obscuring the practices of exclusion always involved in inclusion. While normalization can indeed be a survival strategy and alleviate suffering in individual lives, it will doubtlessly also reinforce structures of power and privilege through which distinctions between normal and pathological and health and illness, just to mention two, are naturalized. Therefore, an equally central aspect of queering biomedicine has to do with a fundamental critical querying of the processes of biomedicalization, the structures of biomedical knowledge and the force of biomedicine as an institution of social control (Clarke et al. 20ro; Zeeman et al. 2014).

While none of us wants to name a queer biomedicine as such, what we propose is a way of rethinking how interventions into the body can fully engage differences rather than aim for the establishment or restoration 
of a normative mode of being in the world, what counts as knowledge in these interventions, and which methodologies produce the most fruitful openings for such critical explorations. In our different approaches to queer and ways of queering biomedical discourse and imaginaries, we embrace an openness and indeterminacy of queer critique, such that its operations, to speak with Eng, Halberstam and Muñoz, "can neither be decided on in advance nor be depended on in the future" $(2005,3$; see also Björklund and Dahl 2020). If queer - as irreducible otherness always already contests norms and explores ways of being anti-capitalist, anti-racist, and anti-ableist and much else, we may be able to think it as a modality through which we reconceptualize what we conceive of as biomedicine. Queer contests normative boundaries of being, refuting dualistic thinking, and proposing ways of capturing the often discounted, disruptive ways of being with a living world. Whether this be an interrogation of linear time (Freeman 2010), a questioning of human embodiment, particularly the supposed divide between the animal and the human (Hird \& Giffney 2008), a critical engagement with how gay and disability politics may be tied to nationalist agendas (Puar 2007; Mitchell \& Snyder 2015), or how the structures of health care may be harmful not only to queers but also in their normative operations (Benjamin 2009; Pollock 20I2), queer is central to how we are thinking the very forms bodies, divisions, institutions of health and care, knowledges, practices and technologies take. Therefore central to this special issue are the following questions: How is biomedicine constructed and practiced in relation to embodied differences? What counts as knowledge and how may this be contested, reimagined and reworked? What are the affective textures of biomedical encounters and practices? How are biomedical interventions into different bodies invoked and represented in visual culture? Who benefits from these ways of framing health and caring for bodies marked by differences, and who does not? How do we make apparent the hierarchies and prejudices which prevent some from gaining access to often basic resources? How do we engage with and potentially reimagine past violence and render this apparent in its related and yet new biotechnological forms? 
In our explorations of biomedicine and queer, we are particularly interested in ways of taking apart the grounding assumptions of what comes to be seen as inherent - usually biological - difference. For example, historically, the categories of diseased and queer are entangled in complex and evolving ways, with some clear overlaps in their meaning and the material realities that shape them (e.g. Treichler 1999; McRuer 2006; Kafer 2013). Above all, the ideas of queering biomedicine reach for the transformative, refuting the logic of cure, seeking instead to explore and contest the social injustices - which are often founded on exclusionary binary thinking - that shape what counts as health. Conventional biomedicine displays a deep attachment to the telos of cure, exemplified in the deferral of death or even the advanced conditions of aging, and remains disturbed by anything that is not susceptible to a positivist approach where there is a definitive end focused on the individual body (Shildrick 2008; Blackman 20I0). What a queer register and the project of queering biomedicine suggest is that there should also be an engagement with healing work that understands the inseparability of body and world, of socio-political economy and matter, of life and death, and recognises our formative and continuously shifting interconnections as human beings with multiple other species or even that we are already multiple beings (Clare 20I7; Clarke \& Haraway 20I8).

This special issue brings together critical analyses of these tensions, ambivalences and developments explored within the Nordic Network Gender, Body, Health (NNGBH) for which the editors are all steering committee members. Since its establishment in 2008 , NNGBH has engaged questions concerning the imaginaries, ethics and politics of health and illness, highlighting the multiplicity, incompleteness and situatedness of any responses. NNGBH embraces the inherent tensions and ambiguities in gender, health and embodiment, and maintains that these demand the continuous interrogation and queering of established paradigms. The articles in this special issue emerge from the NNGBH project The Embodied Self, Health and Emerging Technologies: Implications for Gender and Identity, funded by the Joint Committee for Nordic Research Councils in the Humanities and Social Sciences (NOS-HS) 
and hosted by the department of Ethnology, History of Religions and Gender Studies at Stockholm University 2017-2018. The project set out to explore how newly emerging technologies are shaping the embodied self - a self that is always situated and marked by gendered, racialized, able-bodied and classed differences. Situating emerging technologies within larger economic, societal and cultural developments, NNGBH sought to interrogate the ethical, political and philosophical implications of such practices in the early twenty-first century through three workshops on key developments in prostheses (Stockholm 20I7), selftracking (Helsinki 2017), and transplantation (Copenhagen 2018) - as well as a final conference on graphic medicine (Stockholm 2018). While the workshops explored different technologies and different embodied phenomena, they were connected by several cross-cutting themes including the disruption and rematerialization of bodily boundaries and agency, the (often non-apparent) structures of health in/equalities, the ethics and politics of accounting for experiences of illness, and a persistent queering of biomedical narratives. In addition, the project was situated in an interdisciplinary framework, where we worked with artists to represent and reimagine experiences of emerging technologies, as well as to address the meanings of the relationship between art and illness. The articles in this special issue draw on and develop these central themes, questions and concerns.

The interdisciplinary nature of NNGBH has been an essential tool in bringing together a wide range of approaches that pursue many different avenues of enquiry. The input of visual art or literature, for example, is every bit as revealing as big data or autoethnography, something the work of NNGBH has made clear from its inception. What links interdisciplinary perspectives together - and it is as true of the empirical interests as of the theoretical analyses - is the consistent problematization of the normative binaries, such as health and illness, young and old, mental and physical, and natural and artificial, that map out the healthy body. While the instability of these binaries is seldom fully conceptualized by biomedical researchers, practitioners or end users, what is currently possible in the field of biomedicine reveals a corporeal 
plasticity that casts doubt on the fixity of bodies, their practices, and what can be done to them. For example, lively biological material - tissue, organs, stem cells, genetic material - is moved between bodies and used to manipulate and reshape complex material processes inside living bodies, often with outcomes that are not fully predictable. Indeed, one might argue that such processes undo notions of inside and outside, often bringing the two together in unpredictable ways. Notions of plasticity have been at the forefront of critical disability studies and form an important element in more recently emergent fields such as trans* studies and queer death studies, and much innovative interdisciplinary thinking has been generated in critical medical humanities (Crawford et al. 2020; Whitehead et al. 2016). This special issue draws on and expands this work. While the NNGBH members writing in this special issue approach biomedicine and health from a range of backgrounds, drawing from literary and cultural studies, feminist philosophy and feminist science and technology studies as well as a multitude of theoretical engagements, we are all concerned with the unruly nature of embodiment. For the special issue, as well as for the NNGBH, the aims of interdisciplinary work on biomedicine and health are to provoke questions and dialogue, to queer both materials and methodologies, and to search for alternatives to conventional thought and being.

Interdisciplinary work also makes visible ongoing disagreement as to what constitutes health and biomedicine. Biomedicine and health are not given states but are often used to reflect and create certain measurable biomedical standards through particular bodily practices, social class, gender, ethnicity, age, and geographical and historical location. Also, illness does not necessarily signify identifiable trauma or measurable disease entities; for example, people with chronic pain may face difficulties finding an embodied mechanism that would explain their symptoms (Heshusius 2009). While it is crucial to emphasize that health is not just a state of mind, it is also important to recognize that the absence or presence of biopathologies constitutes just one indicator among many. Just as gender is a matter of performativity (Butler I990; I993) in terms of both bodily and discursive repetition and habituation 
on the personal, institutional and political level, so too health is open to reinterpretation and transformation. With multiple dynamics and synergies in play, there is no fixed point, no stable standard of measurement, and accordingly no biomedical determinism that can follow a simple pattern of cause, effect and interventionary response. Indeed, we engage with biomedicine and health in ways that may challenge conventional understandings of these terms, stretching these definitions to engage with bodies that may be beyond the reach of these categories or to show how biomedicine and health extend into what might be considered separate or discrete areas of research and life itself.

The putting together of this special issue on Queering Health and Biomedicine has taken place parallel to the rise of the current coronavirus pandemic. The pandemic has highlighted the importance of exploring the dynamics of queering, biomedicine and health. The virus is clearly not a universal experience, but instead affects the most marginalized, including the poorest, those living with illnesses and/or disabilities, people of colour and those from LGBTQI+ communities (Gross 2020; Leach Scully 2020; Ryan 2020). Writing now, in early 2021, after a year of pandemic life, many of the undercurrents identified at the beginning of this introduction have intensified. It has become starkly apparent that the premises of neoliberal models of politics and healthcare structure and delivery are not just inappropriate but injurious to the populations they purport to serve. Queering biomedicine and health in this context means, among other things, attending to and questioning what is valued, what kind of life is recognized as worth saving (and by whom), and how health injustices and structural marginalization are amplified and strengthened. At the same time, as many struggle to encompass the scale of the disjunct, there is a sense that nothing will ever be the same again. In short, and on an existential plane, our lives and our associated hopes, expectations, assumptions and fears have been queered in new ways and with new intensity. Yet, here we also express reservation towards what queer may do, attending to its limits, and drawing out how what we might call pandemic discourse (where discourse is the repetitive actions of our embodied being in the world) constantly emphasises 
a return to the very normal that was so damaging to so many. With this in mind, queer is not only the disruptions, the entanglements of bodies and how lives are irrevocably altered by our being in the world. Queer is also the ethico-political drive to interrogate how we might make life liveable (Butler 2004a \& 2004b) in a world that wants to normalize violence against so many, deprive many of resources and keep inequalities in place (Clarke \& Haraway 20I8). Queering Health and Biomedicine is a response to emerging technologies and the role of queer in thinking, doing and being with biomedicine and health.

The pragmatic response to the pandemic in the countries with sufficient resources is to try to mimic the so-called normality of over a year ago by exercising in front of a video screen, by teaching online instead of in a seminar room and homeschooling children, by discreetly making sure our food store cupboards have some supplies, and by respecting the appeal to minimize non-essential use of clinics and surgeries by self-medicating. The resort to personal resourcefulness is at the same time interwoven with a new awareness of the communal underpinnings of life and the deep inequalities that we have tacitly accepted or been forced to live with. Perhaps the very concept of a stable normality will remain unclear, and the validity of queering thought and practice will emerge as one way of dealing with and responding to a pandemic. We suggest that queering biomedicine, in its multiple forms, could provide one way of approaching the pandemic. For example, what does queer mean when daily life is disrupted on a large scale; when huge parts of populations are segregated from others for the supposed sake of their health; when schools, community centres and other key centres of support are closed; when some people have been left at home since the virus was first discovered; and when there is a discussion of the scarcity of the vaccine as a resource quickly taken by the global north with a refusal to release the patent to make more affordable vaccines available? Where does queer intervene when, as has already been articulated, it is clear that the coverage this pandemic receives is due to the fact that it affects affluent, white, Global North dwelling people? We do not seek to undermine the impact COVID-I9 is having globally but rather to 
recognize how all pandemics do not receive the same coverage (Gross 2020), and how a virus reinforces and exacerbates the already existing inequalities and health care injustices. ${ }^{\mathrm{I}}$

This special issue addresses what queer might do in these times, insofar as it offers a critique of ongoing health injustices, explores how bodies are intimately tied to and undo any simple separation between other species and the human, and suggests ways of thinking the present so that we do not stagnate in imagining there is nothing beyond the now. It is these critical and creative responses that we understand the work of queer doing in these uncertain times (e.g., https://matedinburgh. wordpress.com) and to which we aim to contribute in this special issue by looking at the enduring inequalities and prejudices and some queer responses to such injustices. We aim to think creatively and to explore how we may imagine queer ways of being and doing health, biomedicine and emerging technologies, as well as to consider their histories and futures. We see this special issue as an ongoing dialogue for change where violence may be reduced, and we work to reconfigure hierarchical structures and to create space for ever-changing embodiments and modes of belonging.

LUNA dolezal is associate professor of Philosophy and Medical Humanities at the University of Exeter, where she leads the Shame and Medicine Project, funded by the Wellcome Trust, and the Scenes of Shame and Stigma in COVID-I9 Project, funded by the UK Arts and Humanities Research Council. She is the author of The Body and Shame: Phenomenology, Feminism and the Socially Shaped Body (Lexington Books 2015) and coeditor of the books Body/Self/Other: The Phenomenology of Social Encounters (SUNY Press 2017) and New Feminist Perspectives on Embodiment (Palgrave 2018).

LISA FOLKMARSON KÄLL is associate professor of Gender Studies and Philosophy at Stockholm University, Sweden. Her work is primarily in feminist phenomenology, focusing on questions concerning embodied subjectivity, intersubjectivity and otherness. Käll is the 
editor of Bodies, Boundaries and Vulnerabilities: Interrogating Social, Cultural and Political Aspects of Embodiment (Springer 2015) and Dimensions of Pain (Routledge 2013) and coeditor of Feminist Phenomenology and Medicine (SUNY Press 2014).

DONNA MCCORMACK is a Chancellor's Fellow at the University of Strathclyde. She currently holds an AHRC Leadership Fellowship on Transplant Imaginaries. Her first monograph is entitled Queer Postcolonial Narratives and the Ethics of Witnessing (Bloomsbury Press 2014), and she has articles in various journals, including Body \& Society, European Journal of Cultural Studies, Somatechnics and BMJ Medical Humanities, as well as in edited collections such as Bodily Exchanges, Bioethics and Border Crossing (Routledge 2015). She has coedited special issues of Somatechnics and European Journal of Cultural Studies. She is the coordinator of the Nordic Network Gender, Body, Health, as well as a founding member of the Monster Network.

venta oikkonen is Academy Research Fellow in Gender Studies at Tampere University. She is the author of two monographs, Population Genetics and Belonging (Palgrave Macmillan 2018) and Gender, Sexuality and Reproduction in Evolutionary Narratives (Routledge 2013) and has published on cultural aspects of genetic ancestry testing, infectious diseases, vaccination debates and ideas of immunity and embodiment in journals such as Signs, New Genetics and Society, Social Studies of Science, and Science, Technology \& Human Values. She leads a project on gendered chronic illness funded by the Academy of Finland and Kone Foundation.

MARGRIT SHILDRICK is guest professor of Gender and Knowledge Production at Stockholm University, and adjunct professor of Critical Disability Studies at York University, Toronto. Her research covers postmodern feminist and cultural theory, bioethics, critical disability studies and body theory. She is the author of Leaky Bodies and Boundaries (Routledge 1997), Embodying the Monster (Sage 2002) and Dan- 
gerous Discourses of Disability, Sexuality and Subjectivity (Palgrave Macmillan 2009), several edited collections and many journal articles. Her new book (Visceral Prostheses: Somatechnics and Posthuman Embodiment) about the biophilosophical and embodied conjunction of microchimerism, immunology and corporeal anomaly is due early in 2022 .

\section{REFERENCES}

Benjamin, Ruha. Ed. 2019. Captivating Technology: Race, Carceral Technosciences, and Liberatory Imagination in Everyday Life. Durham: Duke University Press.

Björklund, Jenny \& Ulrika Dahl. 2020. "Editorial: A Decade with lambda nordica." lambda nordica 25(I): 7-24. https://doi.org/10.3404I/ln.v25.610

Blackman, Lisa. 2oro. "Bodily Integrity.” Body E Society I6(3): I-9.

Braidotti, Rosi. 2013. The Posthuman. Malden: Polity.

Butler, Judith. 2004a. Precarious Life: The Powers of Mourning and Violence. London: Verso.

-. 2004b. Undoing Gender. New York: Routledge.

-. I993. Bodies that Matter: On the Discursive Limits of 'Sex'. New York: Routledge.

-. 1990. Gender Trouble: Feminism and the Subversion of Identity. New York: Routledge.

Clare, Eli. 2017. Brilliant Imperfection. Durham: Duke University Press.

Clarke, Adele E. \& Donna Haraway (eds.) 2018. Making Kin Not Population. Chicago: Prickly Paradigm Press.

Clarke, Adele E., Laura Mamo, Jennifer Ruth Fosket, Jennifer R. Fishman \& Janet K. Shim (eds.) 2010. Biomedicalization: Technoscience, Health, and Illness in the U.S. Durham: Duke University Press.

Crawford, Paul, Brian Brown and Andrea Charise. 2020. The Routledge Companion to Health Humanities. London: Routledge.

Freeman, Elizabeth. 2oro. Time Binds: Queer Temporalities, Queer Histories. Durham: Duke University Press.

Gross, Lena. 2020. "'Viruses Do Not Discriminate'? Reflecting on Two Pandemics." lambda nordica 25(2): I 28-38.

Heshusius, Lous. 2009. Inside Chronic Pain: An Intimate and Critical Account. Ithaca \& London: Cornell University Press.

Hird, Myra \& Noreen Giffney (eds.) 2008. Queering the Non-Human. Aldershot: Ashgate.

Kafer, Alison. 2013. Feminist, Queer, Crip. Bloomington: Indiana University Press. Leach Scully, Jackie. 2020. "Disablism in a Time of Pandemic.” https://www.ghe.law. ed.ac.uk/disablism-in-a-time-of-pandemic-repost-from-ij-fab/ (Accessed May 29, 2020). 
McRuer, Robert. 2006. Crip Theory: Cultural Signs of Queerness and Disability. New York: New York University Press.

Mitchell, David T. with Sharon L. Snyder. 2015. The Biopolitics of Disability: Neoliberalism, Ablenationalism and Peripheral Embodiment. Ann Arbor: University of Michigan Press.

Pollock, Anne. 201 2. Medicating Race: Heart Disease and Durable Preoccupations with Difference. Durham: Duke University Press.

Puar, Jasbir. 2007. Terrorist Assemblages: Homonationalism in Queer Times. Durham: Duke University Press.

Ryan, Frances. 2020. "When can disabled people leave their homes? It feels like we have been forgotten." https://www.theguardian.com/commentisfree/2020/may/I I/ disabled-people-homes-lockdown (Accessed May i2, 2020).

Shildrick, Margrit. 2008. "Corporeal Cuts: Surgery and the Psycho-social.” Body \& Society I4(I): 3 I-46.

Treichler, Paula A. 1999. How to Have Theory in an Epidemic: Cultural Chronicles of AIDS. Durham: Duke University Press.

Whitehead, Anne \& Angela Woods. 20I6. The Edinburgh Companion to the Critical Medical Humanities. Edinburgh: Edinburgh University Press.

Zeeman, Laetitia, Kay Aranda \& Alec Grant (eds.) 20I 4. Queering Health: Critical Challenges to Normative Health and Healthcare. Ross-on-Wye: PCCS Books.

\section{NOTE}

I. For contemporary feminist, queer and critical, see for example, 'Feminists Theorize COVID-I9: A Symposium': http://signsjournal.org/covid/ 